УДК [(597.8+502.55) : 574.63] (285.3) (477-25)

\author{
В. И. Можановский ${ }^{1}$ Ю. М. Сытник ${ }^{2}$ О. Д. Некрасова ${ }^{3}$ \\ ${ }^{1}$ Киевский наииональный университет им. Тараса Шевченко; \\ ${ }^{2}$ Институт гидробиологии НАН Украины, г. Киев; \\ ${ }^{3}$ Институтт зоологии НАН Украины, г. Киев
}

\title{
СОДЕРЖАНИЕ ТЯЖЕЛЫХ МЕТАЛЛОВ В ОРГАНИЗМЕ БУРЫХ ЛЯГУШЕК ГОРОДСКОЙ ЗОНЫ КИЕВА
}

Досліджено рівні накопичення та розподілу важких металів $(\mathrm{Pb}, \mathrm{Cd}, \mathrm{Zn}, \mathrm{Cu}, \mathrm{Cr})$ в органах та тканинах двох видів жаб (Rana temporaria та R. arvalis) із біотопів, безпосередньо прилеглих до деяких водойм міської зони Кисва.

\author{
V. I. Mozhanovskyi ${ }^{1}$, Y. M. Sytnik ${ }^{2}$, O. D. Nekrasova ${ }^{3}$ \\ ${ }^{1}$ Taras Shevchenko Kyiv National University; \\ ${ }^{2}$ Institute of Hydrobiology of the National Academy of Sciences of Ukraine, Kyiv; \\ ${ }^{3}$ Institute of Zoology of the National Academy of Sciences of Ukraine, Kyiv
}

\section{CONTENT OF THE HEAVY METAL \\ IN THE ORGANISM OF BROWN FROGS OF THE CITY ZONE OF KIEV}

The content and distribution of heavy metals $(\mathrm{Pb}, \mathrm{Cd}, \mathrm{Zn}, \mathrm{Cu}, \mathrm{Cr})$ in organs and tissues of Rana temporaria and $\boldsymbol{R}$. arvalis from biotopes near some reservoirs in the city zone of Kyiv are studied.

\section{Введение}

В последние годы тяжелые металлы являются одними из основных загрязнителей биосферы [20]. Особенностью поведения тяжелых металлов в экосистеме является то обстоятельство, что они не подвержены радиоактивному распаду, как радионуклиды, и не разлагаются, как токсические вещества органической природы, а, однажды попав в экосистему, не исчезают, постоянно перераспределяются по компонентам, накапливаясь в живых организмах различных трофических уровней. Особенно в тех из них, которые являются конечными звеньями трофических цепей или стоят на вершине трофической пирамиды [16]. Для биоиндикации окружающей среды и выявления антропогенного загрязнения урбанизированных территорий все чаще используют животных, жизненный цикл которых связан как с водной, так и с наземной средой. Наиболее пригодны для этих целей земноводные [7]. Одним из преимуществ земноводных в данном случае является их постоянное присутствие в наземных и водных биотопах урбоэкосистем. При этом они реагируют как на краткосрочные залповые выбросы токсических веществ (острый стресс), так и на хроническое загрязнение (хронический стресс) $[9 ; 16]$.

В последнее время проявляется все больший интерес к изучению амфибий как биоиндикаторов состояния окружающей среды [5; 6; 13; 14], особенно в зонах сильного антропогенного пресса, какими являются города с их развитой инфраструктурой и промышленностью. Выбор амфибий для этих целей далеко не случаен. Дело в том, что 
в условиях больших городов довольно трудно собрать большие выборки животных для исследований в естественных условиях, тогда как земноводные всегда доступны исследователям. Довольно важным моментом является то, что популяции амфибий часто изолированы (ограничены застройками, трассами и т. д.) и образуют «островные местообитания», чем объясняется постоянство их мест обитания [8;10].

Батрахофауна г. Киев и его окрестностей довольно слабо изучена, известно несколько работ по изучению видового состава $[9 ; 11 ; 12 ; 19 ; 21]$. Работ по содержанию и распределению тяжелых металлов и других токсических веществ в организме бесхвостых амфибий и вообще земноводных городской зоны Киева в доступных научных печатных изданиях обнаружить не удалось, есть подобные работы по изучению амфибий в некоторых регионах Украины [3; 4] и России [2; 15; 18].

В задачи исследования входило изучение уровней содержания и распределения тяжелых металлов (свинца, кадмия, цинка, меди и хрома) в организме двух видов бурых лягушек Rana temporaria и $R$. arvalis из биотопов, прилегающих к некоторым водоемам городской зоны Киева. Данные исследования проводились впервые.

\section{Материал и методы исследований}

В настоящее время в пределах Киева находится 431 водный объект [1], большинство из которых - озера (129). Практически все они расположены в парковых либо лесопарковых зонах. В этих местах обитают 12 видов земноводных (2 вида - хвостатых, 10 - бесхвостых) [11].

Объектами исследований были два вида бурых лягушек $-R$. temporaria и R. arvalis. Период исследований - 2001 (III-IX месяц) и 2002 (III-IX месяц) годы. Личинки и взрослые особи отлавливались в парковых и лесопарковых зонах возле следующих водоемов (не более 400 м): оз. Синее, оз. Голубое (Виноградарь), оз. Луговое, оз. Опечень-верхнее, оз. Опечень-нижнее, оз. Вербное (Оболонь), оз. Бабье (Труханов остров), пруды № 1 и № 2 (Голосеевский парк), пруд на 4-8 линиях (Пуща-Водица, р. Горенка), пруд «Бетонный» (ул. Зодчих, Южная Борщаговка) и пруд «Бетонный-1» (ул. Булгакова, Южная Борщаговка, р. Нивка), пруд № 15 (Святошин, р. Нивка), а также в самих водоемах. Определяли содержание свинца, кадмия, цинка, меди и хрома в следующих органах и тканях: легкие, печень, кожа, мышцы. Определение проводилось с помощью приборов AAS-3 и AAS-3N («Carl Zeiss», Германия) в пламенном варианте атомизации (пропан - бутан, ацетилен).

Усредненные данные содержания тяжелых металлов $(\mathrm{Pb}, \mathrm{Cd}, \mathrm{Zn}, \mathrm{Cu}, \mathrm{Cr})$ в органах и тканях $R$. temporaria и $R$. arvalis представлены в таблицах 1 и 2 . В то же время особи $R$. temporaria в сборах фиксировались и шести-семилетние. В вышеуказанных таблицах приведены средние результаты для возрастных груп $1^{+} ; 2^{+} ; 3^{+} ; 4^{+} ; 5^{+}$с целью более наглядного сравнения этих двух видов бурых лягушек [17].

\section{Результаты и их обсуждение}

Необходимо отметить, что изучаемые тяжелые металлы зафиксированы во всех исследуемых органах и тканях. Средние величины содержания исследуемых тяжелых металлов у $R$. arvalis выше в сравнении с близкородственным видом $R$. temporaria в биотопах, прилегающих как к озерам, так и к прудам (табл. 1, 2).

Из всех исследованных возрастных групп наибольшее содержание тяжелых металлов обнаружено в организме сеголеток обоих видов бурых лягушек из всех биотопов. С увеличением возраста до $2^{+}$происходит снижение содержания тяжелых металлов в органах и тканях, после чего следует постепенное повышение содержания с его после- 
дующей относительной стабилизацией для особей $3^{+}-5^{+}$-летнего возраста. Изучая органы и ткани лягушек, обнаружили, что наибольшее количество свинца $(23,12 \pm 0,60$ мг/кг) накоплено в печени у $5^{+}$-летних амфибий из прудов Киева (рис.). Содержание хрома в меньшей мере подвержено колебаниям.

Таблииа 1

Содержание тяжелых металлов в органах и тканях Rana arvalis $\left(\right.$ возраст $\left.0^{+}-5^{+}\right)$из биотопов, примыкающих к водоемам городской зоны Киева (2001-2002 гг., $M \pm m$, мг/кг сырой массы)

\begin{tabular}{|c|c|c|c|c|c|c|c|c|}
\hline $\mid$\begin{tabular}{c}
0 \\
0 \\
0 \\
0 \\
\multirow{2}{*}{}
\end{tabular} & Возраст & $n$ & $\begin{array}{l}\text { Органы } \\
\text { и ткани }\end{array}$ & Свинец & Кадмий & Цинк & Медь & Хром \\
\hline \multirow{17}{*}{ 总 } & Сеголетки & 315 & (целиком) & $18,45 \pm 1,73$ & $2,47 \pm 0,21$ & $32,13 \pm 2,81$ & $20,12 \pm 2,30$ & $3,40 \pm 0,14$ \\
\hline & \multirow{4}{*}{$1^{+}$} & \multirow{4}{*}{419} & легкие & $8,45 \pm 0,23$ & $0,95 \pm 0,12$ & $22,14 \pm 0,45$ & $11,07 \pm 0,43$ & $2,45 \pm 0,19$ \\
\hline & & & печень & $9,40 \pm 0,32$ & $1,60 \pm 0,45$ & $18,19 \pm 0,35$ & $19,47 \pm 0,95$ & $2,12 \pm 0,54$ \\
\hline & & & кожа & $9,12 \pm 0,73$ & $0,32 \pm 0,09$ & $10,40 \pm, 60$ & $6,11 \pm 0,60$ & $0,73 \pm 0,12$ \\
\hline & & & мышцы & $7,11 \pm 0,60$ & $0,54 \pm 0,11$ & $6,11 \pm 0,40$ & $0,89 \pm 0,19$ & $1,01 \pm 0,14$ \\
\hline & \multirow{4}{*}{$2^{+}$} & \multirow{4}{*}{277} & легкие & $7,61 \pm 0,95$ & $1,07 \pm 0,21$ & $25,12 \pm 0,32$ & $18,09 \pm 0,61$ & $1,93 \pm 0,24$ \\
\hline & & & печень & $8,45 \pm 0,69$ & $1,23 \pm 0,11$ & $13,17 \pm 1,09$ & $18,11 \pm 0,62$ & $1,90 \pm 0,32$ \\
\hline & & & кожа & $8,45 \pm 0,60$ & $1,01 \pm 0,24$ & $10,12 \pm 0,95$ & $13,14 \pm 0,62$ & $1,09 \pm 0,23$ \\
\hline & & & мышцы & $8,40 \pm 0,52$ & $0,90 \pm 0,17$ & $7,47 \pm 0,75$ & $0.73 \pm 0,14$ & $1,09 \pm 0,10$ \\
\hline & \multirow{4}{*}{$3^{+}$} & \multirow{4}{*}{244} & легкие & $11,43 \pm 0,63$ & $1,10 \pm 0,13$ & $15,50 \pm 0,88$ & $19,20 \pm 0,40$ & $1,99 \pm 0,17$ \\
\hline & & & печень & $11,90 \pm 0,27$ & $1,40 \pm 0,09$ & $14,02 \pm 0,40$ & $19,14 \pm 0,47$ & $1,70 \pm 0,22$ \\
\hline & & & кожа & $9,00 \pm 0,40$ & $0,89 \pm 0,19$ & $10,88 \pm 0,25$ & $11,11 \pm 0,37$ & $1,66 \pm 0,12$ \\
\hline & & & мышцы & $9,00 \pm 0,11$ & $0,81 \pm 0,09$ & $9,00 \pm 0,20$ & $1,63 \pm 0,17$ & $1,50 \pm 0,15$ \\
\hline & \multirow{4}{*}{$5^{+}$} & \multirow{4}{*}{110} & легкие & $13,17 \pm 0,90$ & $1,25 \pm 0,18$ & $19,30 \pm 0,61$ & $19,39 \pm 0,19$ & $2,23 \pm 0,09$ \\
\hline & & & печень & $18,99 \pm 0,95$ & $1,53 \pm 0.17$ & $16,23 \pm 0.17$ & $24,17 \pm 0,93$ & $1,84 \pm 0,09$ \\
\hline & & & кожа & $9,53 \pm 0,17$ & $0,95 \pm 0,17$ & $12,13 \pm 0,47$ & $18,19 \pm 0,95$ & $1,71 \pm 0,09$ \\
\hline & & & мышцы & $11,73 \pm 0,61$ & $0,92 \pm 0,14$ & $12,45 \pm 0,61$ & $2,12 \pm 0,61$ & $1,59 \pm 0,10$ \\
\hline \multirow{17}{*}{ 鸽 } & Сеголетки & 189 & (целиком) & $23,12 \pm 0,45$ & $2,39 \pm 0,19$ & $30,73 \pm 3,11$ & $23,73 \pm 0,17$ & $2,90 \pm 0,17$ \\
\hline & \multirow{4}{*}{$1^{+}$} & \multirow{4}{*}{169} & легкие & $9,12 \pm 0,43$ & $1,01 \pm 0,11$ & $21,73 \pm 0,41$ & $14,11 \pm 0,35$ & $2,73 \pm 0,21$ \\
\hline & & & печень & $9,70 \pm 0,61$ & $0,99 \pm 0,21$ & $22,19 \pm 0,11$ & $13,70 \pm 0,81$ & $2,15 \pm 0,61$ \\
\hline & & & кожа & $9,17 \pm 0,61$ & $0,95 \pm 0,14$ & $12,40 \pm 2,70$ & $13,14 \pm 0,23$ & $1,61 \pm 0,18$ \\
\hline & & & мышщы & $8,14 \pm 0,17$ & $0,61 \pm 0,17$ & $0,79 \pm 0,61$ & $0,94 \pm 0,23$ & $1,43 \pm 0,17$ \\
\hline & \multirow{4}{*}{$2^{+}$} & \multirow{4}{*}{107} & легкие & $8,05 \pm 0,77$ & $1,11 \pm 0,04$ & $30,11 \pm 0,97$ & $20,11 \pm 0,13$ & $1,80 \pm 0,40$ \\
\hline & & & печень & $8,90 \pm 0,31$ & $1,37 \pm 0,16$ & $13,70 \pm 0,63$ & $24,00 \pm 0,17$ & $1,93 \pm 0,40$ \\
\hline & & & кожа & $9,15 \pm 0,13$ & $1,25 \pm 0,09$ & $12,30 \pm 0,93$ & $19,14 \pm 0,80$ & $1,20 \pm 0,09$ \\
\hline & & & мышщы & $8,20 \pm 0,11$ & $0,99 \pm 0,08$ & $8,12 \pm 0,61$ & $0,80 \pm 0,17$ & $1,17 \pm 0,10$ \\
\hline & \multirow{4}{*}{$3^{+}$} & \multirow{4}{*}{141} & легкие & $12,15 \pm 0,25$ & $1,13 \pm 0,07$ & $16,66 \pm 0,27$ & $20,11 \pm 0,73$ & $1,88 \pm 0,03$ \\
\hline & & & печень & $14,00 \pm 0,40$ & $1,45 \pm 0,07$ & $14,25 \pm 0,61$ & $19,27 \pm 0,11$ & $1,80 \pm 0,17$ \\
\hline & & & кожа & $9,90 \pm 0,14$ & $0,93 \pm 0,13$ & $13,15 \pm 1,11$ & $15,12 \pm 0,60$ & $1,66 \pm 0,25$ \\
\hline & & & мышщы & $8,00 \pm 0,40$ & $0,90 \pm 0,07$ & $7,73 \pm 0,61$ & $2,11 \pm 0,40$ & $1,43 \pm 0,11$ \\
\hline & \multirow{4}{*}{$5^{+}$} & \multirow{4}{*}{87} & легкие & $13,40 \pm 0,23$ & $1,40 \pm 0,09$ & $18,40 \pm 0,11$ & $19,01 \pm 0,23$ & $2,20 \pm 0,23$ \\
\hline & & & печень & $20,11 \pm 0,14$ & $1,00 \pm 0,19$ & $18,40 \pm 0,60$ & $29,19 \pm 0,41$ & $1,90 \pm 0,11$ \\
\hline & & & кожа & $10,11 \pm 0,17$ & $0,99 \pm 0,03$ & $17,60 \pm 0,90$ & $21,13 \pm 0,60$ & $1,90 \pm 0,41$ \\
\hline & & & мышщы & $12,15 \pm 0,61$ & $1,00 \pm 0,09$ & $13,00 \pm 0,17$ & $3,17 \pm 0,60$ & $1,65 \pm 0,17$ \\
\hline
\end{tabular}

У половозрелых особей $R$. arvalis и $R$. temporaria более высокие уровни содержания тяжелых металлов обнаружены у первого из вышеуказанных видов. Сравнивая два вида по степени накопления тяжелых металлов, необходимо отметить большее содержание свинца, цинка и хрома у $R$. arvalis практически во всех исследуемых образцах. Если в качестве биондикаторов (биомаркеров) состояния окружающей среды ис- 
пользовать органы и ткани бурых лягушек, то можно сделать вывод, что участки биотопов около прудов более загрязнены тяжелыми металлами, чем возле озер.

Таблииа 2

Содержание тяжелых металлов в органах и тканях Rana temporaria (возраст $0^{+}-5^{+}$) из биотопов, примыкающих к водоемам городской зоны Киева (2001-2002 гг., $M \pm m$, мг/кг сырой массы)

\begin{tabular}{|c|c|c|c|c|c|c|c|c|}
\hline 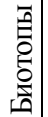 & Возраст & $n$ & $\begin{array}{l}\text { Органы } \\
\text { и ткани }\end{array}$ & Свинец & Кадмий & Цинк & Медь & Хром \\
\hline \multirow{17}{*}{ 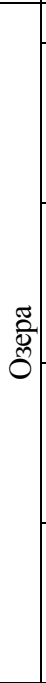 } & Сеголетки & 137 & (целиком) & $17,95 \pm 0,64$ & $2,01 \pm 0,40$ & $30,17 \pm 2,01$ & $25,13 \pm 1,99$ & $2,99 \pm 0,23$ \\
\hline & \multirow{4}{*}{$1^{+}$} & \multirow{4}{*}{95} & легкие & $7,93 \pm 0,19$ & $1,43 \pm 0,15$ & $23,40 \pm 0,31$ & $10,09 \pm 0,15$ & $2,30 \pm 0,60$ \\
\hline & & & печень & $8,99 \pm 0.61$ & $1,88 \pm 0,23$ & $16,11 \pm 0,40$ & $17,19 \pm 0,61$ & $2,00 \pm 0,25$ \\
\hline & & & кожа & $8,60 \pm 0,19$ & $0,73 \pm 0,19$ & $9,12 \pm 0,11$ & $9,12 \pm 0,92$ & $0,90 \pm 0,11$ \\
\hline & & & мышцы & $9,42 \pm 0,61$ & $0,85 \pm 0,11$ & $10,11 \pm 0,90$ & $0,73 \pm 0,03$ & $1,00 \pm 0,19$ \\
\hline & \multirow{4}{*}{$2^{+}$} & \multirow{4}{*}{139} & легкие & $7,30 \pm 0,60$ & $0,90 \pm 0,11$ & $24,00 \pm 0,11$ & $14,11 \pm 0,60$ & $1,80 \pm 0,04$ \\
\hline & & & печень & $7,11 \pm 0,60$ & $1,14 \pm 0,09$ & $11,80 \pm 0,09$ & $16,80 \pm 0,40$ & $1,85 \pm 0,20$ \\
\hline & & & кожа & $7,90 \pm 0,61$ & $0,90 \pm 0,11$ & $9,15 \pm 0,60$ & $11,11 \pm 0,17$ & $1,01 \pm 0,13$ \\
\hline & & & мышцы & $6,60 \pm 0,14$ & $0,77 \pm 0,07$ & $6,32 \pm 0,16$ & $0,70 \pm 0,11$ & $1,01 \pm 0,11$ \\
\hline & \multirow{4}{*}{$3^{+}$} & \multirow{4}{*}{87} & легкие & $10,12 \pm 0,43$ & $0,99 \pm 0,23$ & $16,00 \pm 1,23$ & $13,11 \pm 0,20$ & $1,80 \pm 0,27$ \\
\hline & & & печень & $12,40 \pm 0,60$ & $1,29 \pm 0,09$ & $13,90 \pm 0,60$ & $18,17 \pm 0,60$ & $1,60 \pm 0,17$ \\
\hline & & & кожа & $9,00 \pm 0,17$ & $0,71 \pm 0,17$ & $9,43 \pm 0,60$ & $11,19 \pm 0,60$ & $1,53 \pm 0,27$ \\
\hline & & & мышцы & $7,90 \pm 0,64$ & $0,90 \pm 0,11$ & $6,90 \pm 0,40$ & $2,00 \pm 0,42$ & $1,47 \pm 0,27$ \\
\hline & \multirow{4}{*}{$5^{+}$} & \multirow{4}{*}{79} & легкие & $14,00 \pm 0,60$ & $1,01 \pm 0,17$ & $17,70 \pm 0,44$ & 19,20 & $2,10 \pm 0,60$ \\
\hline & & & печень & $17,40 \pm 0,60$ & $1,40 \pm 0,09$ & $16,00 \pm 0,09$ & $20,11 \pm 0,90$ & $1,60 \pm 0,12$ \\
\hline & & & кожа & $8,60 \pm 0,70$ & $0,87 \pm 0,06$ & $10,09 \pm 0,60$ & $17,90 \pm 0,60$ & $1,80 \pm 0,30$ \\
\hline & & & мышцы & $10,95 \pm 0,89$ & $0,89 \pm 0,11$ & $11,11 \pm 0,60$ & $3,02 \pm 0,40$ & $1,29 \pm 0,41$ \\
\hline \multirow{17}{*}{$\vec{\theta}$} & Сеголетки & 129 & (целиком) & $24,00 \pm 0,23$ & $2,40 \pm 0,11$ & $27,79 \pm 1,17$ & $23,11 \pm 0,19$ & $2,47 \pm 0,20$ \\
\hline & \multirow{4}{*}{$1^{+}$} & \multirow{4}{*}{99} & легкие & $7,40 \pm 0,60$ & $1,01 \pm 0,07$ & $20,12 \pm 0,69$ & $11,15 \pm 0,60$ & $2,40 \pm 0,11$ \\
\hline & & & печень & $8,60 \pm 0,73$ & $1,40 \pm 0,25$ & $25,49 \pm 0,60$ & $21,40 \pm 0,90$ & $2,00 \pm 0,11$ \\
\hline & & & кожа & $6,15 \pm 0,17$ & $1,20 \pm 0,17$ & $13,40 \pm 0,65$ & $14,00 \pm 0,69$ & $1,40 \pm 0,11$ \\
\hline & & & мышцы & $6,93 \pm 0,60$ & $0,83 \pm 0,23$ & $8,12 \pm 0,69$ & $1,15 \pm 0,13$ & $1,50 \pm 0,10$ \\
\hline & \multirow{4}{*}{$2^{+}$} & \multirow{4}{*}{141} & легкие & $7,97 \pm 0,61$ & $1,10 \pm 0,12$ & $25,11 \pm 0,30$ & $18,41 \pm 0,69$ & $1,90 \pm 0,17$ \\
\hline & & & печень & $8,00 \pm 0,60$ & $1,25 \pm 0,11$ & $12,90 \pm 0,11$ & $29,80 \pm 0,60$ & $1,75 \pm 0,40$ \\
\hline & & & кожа & $7,40 \pm 0,60$ & $1,17 \pm 0,40$ & $10,70 \pm 0,07$ & $18,11 \pm 0,69$ & $1,17 \pm 0,10$ \\
\hline & & & мышцы & $8,00 \pm 0,60$ & $0,83 \pm 0,11$ & $7,99 \pm 0,13$ & $0,89 \pm 0,11$ & $1,10 \pm 0,07$ \\
\hline & \multirow{4}{*}{$3^{+}$} & \multirow{4}{*}{85} & легкие & $10,05 \pm 0,20$ & $1,23 \pm 0,07$ & $20,11 \pm 0,43$ & $23,12 \pm 0,17$ & $1,94 \pm 0,19$ \\
\hline & & & печень & $12,20 \pm 0,60$ & $1,40 \pm 0,12$ & $15,70 \pm 0,60$ & $29,15 \pm 0,61$ & $1,90 \pm 0,09$ \\
\hline & & & кожа & $8,00 \pm 0,60$ & $0,89 \pm 0,11$ & $16,45 \pm 0,37$ & $19,40 \pm 0,30$ & $1,70 \pm 0,09$ \\
\hline & & & мышцы & $9,12 \pm 0,89$ & $0,88 \pm 0,09$ & $8,18 \pm 0,90$ & $5,43 \pm 0,88$ & $1,50 \pm 0,04$ \\
\hline & \multirow{4}{*}{$5^{+}$} & \multirow{4}{*}{61} & легкие & $14,20 \pm 0,40$ & $1,51 \pm 0,11$ & $19,00 \pm 0,17$ & $24,01 \pm 0,61$ & $1,90 \pm 0,11$ \\
\hline & & & печень & $23,12 \pm 0,60$ & $1,41 \pm 0,19$ & $13,20 \pm 0,41$ & $23,77 \pm 0,99$ & $1,73 \pm 0,10$ \\
\hline & & & кожа & $13,20 \pm 0,33$ & $1,20 \pm 0,09$ & $17,15 \pm 0,69$ & $17,40 \pm 0,90$ & $1,80 \pm 0,17$ \\
\hline & & & мышцы & $14,17 \pm 0,90$ & $1,20 \pm 0,12$ & $15,50 \pm 0,43$ & $6,00 \pm 0,30$ & $1,60 \pm 0,10$ \\
\hline
\end{tabular}

Интересно, что на территории города встречались и шести-семилетние особи $R$. temporaria. В популяциях $R$. arvalis особей старше пятилетнего возраста, как указывалось выше, зафиксировать не удалось. Известно, что специфика демографии городских популяций $R$. temporaria выражается в преобладании типа особей, которые быстро растут, раньше начинают размножаться и имеют более низкую продолжительность жизни. Для них также характерно укорочение трофических связей и интенсификация обменных процессов. По мнению ряда авторов, существование популяций в условиях 
загрязненной и преобразованной среды обитания обеспечивается благодаря определенным изменениям в стратегии размножения, использования пищевых ресурсов, адаптация амфибий происходит за счет отдельных особей $[2-4 ; 11 ; 12 ; 15 ; 18 ; 19 ; 21]$.

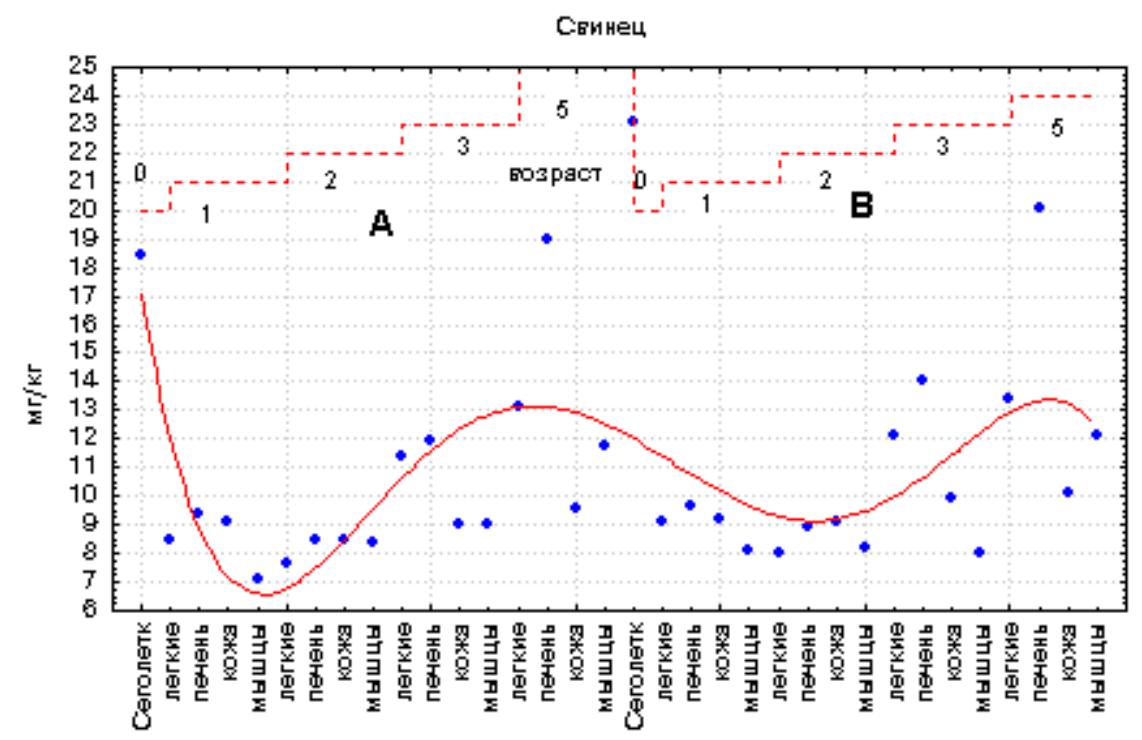

Рис. Содержание свинца в органах и тканях

Rana arvalis в зависимости от возраста в озерах $(A)$ и прудах (B)

\section{Заключение}

Анализ распределения тяжелых металлов в организме двух видов бурых лягушек ( $R$. arvalis и $R$. temporaria), обитающих в городской зоне Киева, свидетельствует о значительном полиметаллическом загрязнении. Следует отметить большее загрязнение прудовых экосистем по сравнению с озерными, равно как и непосредственно прилегающих биотопов. Необходимо отметить, что даже близкородственные виды бурых лягушек имеют разнонаправленный характер адаптивных особенностей, которые сформировались в условиях антропогенного пресса такого мегаполиса как Киев.

В дальнейшем планируется проведение дополнительных исследований, связанных с изучением сезонной динамики накопления тяжелых металлов разными возрастными группами $R$. arvalis и $R$. temporaria, а также изучение спектров питания и их динамики у популяций в условиях городской агломерации Киева.

\section{Библиографические ссылки}

1. Афанасьев С. А. Характеристика гидробиологического состояния разнотипных водоемов г. Киева // Вопросы экологии. - 1996. - № 1-2. - С. 112-118.

2. Вершинин В. Л. Адаптивные и микроэволюционные процессы в популяциях земноводных урбанизированных территорий // Вопросы герпетологии. Матер. І Съезда герпетологического общества им. А. М. Никольского. - Пущино - Москва: МГУ, 2001. - С. 56-57.

3. Мисюра А. Н. Экология фонового вида амфибий центрального степного Приднепровья в условиях промышленного загрязнения водоемов. Автореф. дис. ... канд. биол. наук. - Д., 1989. - 16 c.

4. Мисюра А. Н. Использование земноводных для оценки состояния урбанизированных территорий и прилегающих водных акваторий / А. Н. Мисюра, В. Я. Гассо, А. А. Марченковская // II Междунар. конф. «Экологические и гидрометеорологические проблемы больших городов и промышленных зон». - С-Пб, 2002. - С. 56. 
5. Можановський В. І. Використання амфібій для біотестування стану якості навколишнього середовища урбанізованих територій (огляд) // Вісник Київського національного. університету. Серія: Біологія. - 2003. - Вип. 39-41. - С. 88-90.

6. Можановський В. І. Вміст важких металів в органах та тканинах Bufo viridis з міської зони Києва // Наукові записки Тернопільского педуніверситету ім. В. Гнатюка. Серія: Біологія. - 2003. - Т. 2 (21). - С. 76-79.

7. Можановський В. І. Вміст та розподіл важких металів $(C d, P b, Z n, C u)$ в організмі Rana ridibunda та Bufo viridis з деяких водойм міської зони Києва // Біорізноманіття. Екологія. Еволюція. Адаптація. Матер. конф., присвяченої 180-річчю 3 дня народження Л. С. Ценковського. - Одеса, 2003. - С. 102.

8. Можановский В. И. Тяжелые металлы в организме бурых лягушек (Rana temporaria и R. arvalis) из наземных биотопов водоемов городской зоны Киева / В. И. Можановский, Ю. М. Сытник // Zoocenozis-2005. Біорізноманіття та роль зооценозу у природних і антропогенних екосистемах. Матер. ІІІ Міжнар. конф. - Д.: Вид-во ДНУ, 2005. - С. 374-376.

9. Некрасова О. Д. Амфибии урбанизированных территорий // Фальцфейнівські читання. Херсон, 1999. - С. 219-221.

10. Некрасова О. Д. Биотические компоненты урболандшафтов (на примере герпетокомплексов) // Ландшафт - основа науки. - Винница, 2000. - С. 153-156.

11. Некрасова О. Д. Некоторые особенности распределения батрахофауны Киева // Фальцфейнівські читання. - Херсон, 2000. - С. 136-138.

12. Некрасова О. Д. Структура популяций и гибридизация зеленых лягушек Rana esculenta complex урбанизированных территорий Среднего Приднепровья // Автореф. дис. ... канд. биол. наук. - К., 2002. -21 с.

13. Некрасова О. Д. Биоиндикационное значение пространственного распределения популяций животных урболандшафтов на примере амфибий // Роль экологического пространства в обеспечении функционирования живых систем. - Елец, 2005. - С. 30-31.

14. Некрасова О. Д. Оцінка стану навколишнього середовища за допомогою видівбіоіндикаторів на прикладі амфібій // Сучасні проблеми біології. Зб. Міжнар. конф. - Запоріжжя, 2007. - С. 184-186.

15. Никаноров А. М. Биомониторинг металлов в пресноводных екосистемах / А. М. Никаноров, А. В. Жулидов. - Л.: Гидрометеоиздат, 1991. - С. 8-39.

16. Одум Ю. Экология: В 2 т. - М.: Мир, 1986. - Т. 1. - 328 с; Т. 2. - 376 с.

17. Смирина Э. М. Методика определения возраста амфибий и рептилий по слоям в кости // Руководство по изучению земноводных и пресмыкающихся. - К., 1989. - С. 143-153.

18. Структура и функциональная роль животного населения в природных и трансформированных экосистемах. Тез. І Междунар. конф. - Д.: ДНУ, 2001. - 220 с.

19. Таращук С. В. Герпетофауна Києва та його околиць // Урбанізоване навколишнє середовище: охорона природи та здоров'я людини. - К., 1996. - С. 224-225.

20. Химические и биологические методы в охране окружающей среды от загрязнения тяжелыми металлами // Тез. докл. Всесоюзн. конф. 18-21.09.1990 г., Усть-Каменогорск. - М.: ВНИИСЭНТИ, 1990. - 99 с.

21. Шарлеманъ Э. В. Заметка о фауне пресмыкающихся и земноводных окрестностей Киева // Матер. к познанию фауны юго-западной России. - К., 1917. - С. 1-17.

Надійшла до редколегії 05.08.2007 